УДК 1.141.304.-004.5

DOI https://doi.org/10.32837/apfs.v0i26.902

\author{
О. В. Онищук \\ ORCID ID: 0000-0002-8064-1953 \\ кандидат філософських наук, доиент, \\ доиент кафедри філософіі \\ Національного університету «Львівська політехніка»
}

\title{
ДИНАМІКА ТРАНСФОРМАЦІЇ КОГНІТИВНИХ СТРАТЕГІЙ В УМОВАХ ІНФОРМАЦІЙНОГО ПЛЮРАЛІЗМУ
}

3 огляду на полісегментну та полімодальну структуру мережі, медіареальність сучасного інформаційного суспільства, високу швидкість поширення інформаційних потоків, а також ступінь доступу до інтернет-мережі можна говорити про плюралістичність когнітивних стратегій і моделей індивіда. Остання зумовлена тим, що в мережі співіснують величезні масиви різноманітних даних, відомостей, переплітається істинна та хибна інформація, фейки, викривлення та багато іншого. Бачимо також, що сучасне розмивання меж між наукою та різними когнітивними практиками призвели до ревізії норм, регуляторів і засобів пізнання, до трансформації традиційної гносеологічної проблематики. Конвергенція інформаційних мережевих і когнітивних стратегій покликана збільшувати можливості інтелекту людини. У такому контексті актуальною бачиться проблема стратегій, які вибирає людина в пізнавальному процесі і яким чином вони впливають на картину iї реальності. Метою розвідки є аналіз змісту концепту «когнітивна стратегія», окреслення домінантних видів інтегративних когнітивних схем і стратегій у мережі та медіарельності, а також особливостей впливу останніх на формування картини реальності індивіда.

Проблеми пов'язані 3 функціонуванням і впливом медіа, тлумачення соціокультурних трансформацій і становища людини в інформаційному суспільстві розглядали у своїх працях Ж. Бодріяр, Д. Ваттімо, П. Вірільо, М. Кастельс, Н. Луман, М. Маклюен та інші. Соціокультурні практики конструювання реальності в медіа та інтернет-мережі є темою дослідження В. Ліппмана, П. Лазарсфельда, В. Флюссера, К. Ленга, вітчизняних дослідників Г. Почепцова, Д. Кулеби та інших. Аналіз медіареальності в інформаційному суспільстві представлено в працях 3. Баумана, Л. Флоріді, Ж. Ліповецькі, Г. Маркузе, Н. Постмана та інших.

Нова інформаційна парадигма конвергентних технологій у сучасній культурі, що виникає наприкінці 90-х рp. XX ст. (знаходимо її ідейне підгрунтя, зокрема, в «Комп'ютопії» М. Кастельса), стосується найперше технологічних аспектів суспільства і проявляється у зближенні та взаємопереплетенні окремих наук і способів пізнання, проявляючись у домінуванні міждисциплінарних досліджень. Сьогодні конвергентні технології набувають соціально-гуманітарного виміру, відкриваючи перспективи розширення можливостей тіла людини, конструювання систем штучного інтелекту та іншого. Медіатизація особистості поряд із візуалізацією мислення актуалізують проблему осмислення названих процесів. М. Маклюен, М. Постер та інші вчені доводять, що способи трансляції інформації, найперше через медіа, впливають на сприйняття реальності та життя людини загалом.

Можемо констатувати, що однією із системних основ сучасної культури є медійність, яка постає у вигляді інформаційного публічного простору, де всі індивіди зрівняні в контексті самоцінності комунікації. У цьому просторі раціональне часто замінюється емоційним, а сам контент спрощується, у результаті чого сприймається легко, у вигляді переважно готових ідей. У сучасній медіареальності панує тотальний надлишок інформації (дуже часто фейкової, низької якості), викликаючи в людини не тільки розчарованість чи розгубленість, а й страждання (наприклад, у формах відрази, агресії, байдужості, депресіі). Всепроникність медіаобразів майже в усі сфери життя випереджує процес їхнього аналізу на фоні легкого сприйняття, семантичного плюралізму та складності (а то й неможливості верифікації). Проте найчастіше таке сприйняття поверхневе внаслідок незануреності в об'єкт сприйняття через відвертання уваги, розпорошеність та агресивність, з якою інформація атакує канали мереж (зауважимо, що відомі сучасні дослідники, як-от французький філософ техніки Б. Стіглер чи британський історик Н. Фергюсон, наголошують, що алгоритми мережі свідомо маніпулюють людиною задля обслуговування інтересів ринку, а свобода в ній насправді доволі обмежена).

Які ж особливості взаємодії людини з медіареальністю та інтернет-мережею і як останні впливають на когнітивні здібності людини? На думку Г. Почепцова [5, с. 86], медіа дають нам не тільки події, а й правильні варіанти реагування на них. Медіа створюють систему емоційного реагування, 
занурюючи людей у чуже життя більше, аніж у своє власне; вони також дають інтерпретацію подій, утримуючи чи змінюючи домінантну модель світу. Навіть сучасні війни найперше мають когнітивний характер. "Сучасна людина поступово втрачає саму здатність відчувати самостійно, усі ці реакції їй диктує штучна людина, створена медіа. Це інформаційні бульбашки, інформаційні каскади, емоційне зараження, досліджене Facebook, - усе це приклади створення єдиних, можливо, синтетичних почуттів. Але вони більш яскраві, більш доступні, менш витратні, тобто більш конкурентні, ніж власні почуття людини. Це систематика створення єдиного емоційного реагування. Люди, не помічаючи цього, занурені в чуже життя більше, ніж у своє» [5, с. 87].

Інший український дослідник М. Ожеван наголошує, що «головна небезпека ...полягає в тому, що масова інформація перестає існувати в цілісному вигляді, а фрагментується, і ці фрагменти не співвідносяться безпосередньо один 3 одним. Деякі з них не є вартими довіри (фейкові новини, «альтернативні факти»). Деяким, навпаки, треба вірити... Тому виникає когнітивне перевантаження, яке послаблює здатність перевіряти й диференціювати інформацію та вбиває саме прагнення до пошуку достовірної інформації»[3, с. 23-24]. Багато помилок також виникає через схильність людини перенавантажувати реальність тим, що тільки видається, зводячи одиничні факти на рівень теорії або ж безпідставно корелюючи невідповідні між собою факти, порушуючи закони логіки та правила виводів.

Т. Гарріс [12] зауважує, що соцмережі діють на нас гіпнотичним чином, змушуючи постійно бути присутніми в них, взаємодіяти з тим, що пропонується. Так вибудовується суспільна й особиста думка, розмивається почуття відповідальності, оскільки зазвичай майже ніхто не відповідає за істинність інформації, яку викладає (на відміну, скажімо, від інформації, яка транслюється в живому процесі спілкування).

Німецький філософ і теоретик медіа В. Флюсcep [7] виокремив чотири тенденції, які трансформують традиційний погляд на світ і людину, - нейропсихологічну, фізичну, психологічну та екзистенційно-гносеологічну. Згідно з його ідеєю, людська ідентичність у мережевому суспільстві найсуттєвіше розкривається через інформаційний аспект. Одна з тенденцій розвитку сучасної людини полягає у формуванні особливої гносеологічної установки в пізнавальному процесі, коли суб'єкт та об'єкт екстраполюються 3 процесу пізнання під час багатьох зв'язків. В. Флюссер уподібнює процес сприйняття людини 3 цифровими процесами. Люди подібно до комп'ютерів відображають світ. Сьогодні код і знання формують життєвий світ людини. Людське «Я» втратило стійкість та єдність, перестало бути автономним, набувши вигляду згустку інформації. Воно ніби розчинилося в інформаційних потоках і втратило власну ідентичність. Бачимо, що сьогодні стали популярними інформаційні мережеві підходи до тлумачення мови, свідомості, пізнання, культури. Це призвело до переосмислення онтологічних підстав людської екзистенції (коли, скажімо, у радикальних ідеях трансгуманізму подають як інформацію, яка в майбутньому зможе досягти безсмертя через власний запис на інформаційний носій).

Для осмислення вибраного нами аспекту названої проблеми також необхідно розібратися з визначенням когнітивних схем і стратегій. Поняття «когнітивні схеми» вперше використовує британський психолог Ф. Бартлет, маючи на увазі, що формування нашого сприйняття світу є результатом абстрактних ментальних структур. «Когнітивні схеми структурують дані людської свідомості і психіки на основі найширших уявлень про можливу будову реальності (або об'єкта) взагалі. Надалі вони виконують роль структур, що зумовлюють вибіркове ставлення людини до того, із чим вона стикається»[4, с. 85]. Загалом, можна виділити такі види схем, як особистісні, соціальні, схеми подій та інші. Схеми впливають на нашу орієнтацію у світі, інтерпретації фактів і явищ, інформації загалом.

Когнітивна стратегія (за Ван Дейком [1]) - це пізнавальна здібність людини, що пов'язана 3 обробкою та представленням інформації. Також такі стратегії можна тлумачити як особливі схеми розуміння реальності. У структуру когнітивних стратегій можна внести й залежність від суб'єкта пізнання, і залежність від контексту ситуації, і ступінь усвідомленості, і цілі суб'єкта та інше. Немає чіткої дефініції поняття «когнітивні стратегії», як і їхньої класифікації. Ван Дейк розуміє під стратегією знання про процеси розуміння. Можемо сказати, що когнітивні стратегії - це спосіб взаємодії зі світом у процесі пізнання з урахуванням вибірковості процесу сприйняття реальності. Тому дослідники [8] говорять про такі типи когнітивних стратегій, як культурні, соціальні, граматичні, комунікативні та інші. Вибір стратегії залежить від багатьох чинників: умов і засобів пізнавальної діяльності, психологічних та інтелектуальних характеристик суб'єкта пізнання, способу пізнавальної діяльності та іншого. Наше знання про світ організовується у свідомості у вигляді фреймів (епістемологічних одиниць), які визначають наше сприйняття світу.

Кожен індивід здатен розширювати чи звужувати власні когнітивні моделі. Нові когнітивні схеми і стратегії виникають у результаті поєднання різних компонентів медіареальності, вербальних i невербальних (як-от колір, звук, графіка та інше) 3 когнітивними структурами людини. 
Зазвичай об'єктом пізнання найчастіше є те, що захоплює увагу індивіда та має ціннісний вимір щодо буття людини. Цінність і значимість релевантні між собою. Наприклад, однією зі стратегій є створення ментальних монополій та емоційних наративів великими корпорація на зразок Apple, Netflix чи Google шляхом продажу мрії і створення стійкої установки в мільйонів людей, що їм необхідне саме це. Навіть якщо людина вагається, чи їй потрібен такий продукт, їй нав'яжуть думку, що потрібен. Тут уже сфера діяльності економіки уваги та новітніх технологій конструювання смислу в медіаепоху (скажімо, через соцмережі як потужні генератори віртуальних світів). Якщо в такій ситуації за суперечливості фрагментів інформації в процесі пізнання відбувається когнітивний конфлікт, коли ускладнюється ії аналіз, класифікація, то в такому разі всі сили йдуть на пошук несуперечливої інформації та пошук нових схем інтерпретації. «За кожним медіаповідомленням лежать наслідки, оскільки в ньому є не тільки інформація, але й відсилання до тієї чи іншої картини світу. Коли ця картина світу конфліктує 3 «нашою», ми вважаємо таке медіаповідомлення неправильним і неправдивим» [5, с. 87].

Особливістю когнітивних стратегій (схем) є те, що вони залежать від ментальних репрезентацій реальності, від модальностей досвіду, від механізмів інтелектуального та емоційного контролю під час переробки інформації. Когнітивні схеми постають, відповідно, своєрідними інструментами для побудови індивідуальної картини світу. Це ніби посередники між суб'єктивним ментальним світом людини й реальним світом. «Важливим наслідком ідеї про фундаментальну роль ситуаційних моделей в пізнанні є теза про те, що люди діють не стільки в реальному світі і говорять не стільки про нього, скільки про суб'єктивні моделі явищ і ситуацій дійсності» $[1$, с. 9].

Отже, можна стверджувати, що когнітивні стратегії постають своєрідними концептуальними матрицями на основі різних установок (наприклад, таких як ціннісні, самоідентифікаційні, цільові та інші) в просторі свідомості індивіда. У сучасному світі ці стратегії є одними з найважливіших мегатехнологій поряд з інформаційними чи нанотехнологіями. Конвергенція таких стратегій і технологій відкриває багато нових можливостей у житті людини й суспільства. Розуміння механізмів функціонування когнітивних стратегій дає змогу продемонструвати, як медійні продукти, знаки й символи, взаємодіючи зі свідомістю суб'єкта, створюють смисли і картини репрезентації реальності з використанням різних семіотичних систем та інтеграцією різних ідейних компонентів. Можна стверджувати, що когнітивні зміни відбуваються завдяки створенню нових ментальних структур або трансформації вже наяв- них. Відмінності у сприйнятті й переробці інформації полягають у різних ситуаційних моделях. Процес пізнання і створення цих моделей є гнучким і полягає у відборі найвагомішої інформації, тобто такої, яка найкраще адаптує до світу через використання і трансляцію певних культурних, ментальних, соціальних і інших програм. Фундаментальним когнітивним контекстом, на який накладаються всі інші контексти (історичний, соціокультурний і т. д.), є система особистісного знання. Вона характеризується динамічністю, а також тим, що у процесі власного розвитку на основі взаємодії раціонально-ірраціональних чинників породжується і доповнюеться новими смисловими компонентами. Тут доречно буде згадати про ідеї Д. Канемана. Зважаючи на його концепцію [11], можна говорити про швидке (Система 1) і повільне (Система 2) мислення, які безпосередньо впливають на когнітивні рішення людини. I проблема полягає в тому, що повільне мислення часто замінюється на швидке (інакше кажучи, підміна раціонально-критичного мислення на емоційну реакцію й поведінку, що з неї випливає). Чому так? Бо швидке мислення оперує сильною і яскравою картинкою, а також унаслідок багатократної повторюваності людина легше вірить у те, що їй пропонують, навіть якщо це відверта брехня. Окрім того, саме Система 1 є головним джерелом формування переконань і вибору, хоча на цьому рівні вибір часто є помилковим (бо багато чого, що ми вважаємо істинним переконаннями, $€$ порушенням законів логіки, зведення одиничних фактів на рівень теорій, додумування того, чого насправді нема і т. ін., а також на цьому рівні потрібно докласти багато зусиль для ухвалення рішення). Тому, ухвалюючи рішення, варто відвертати увагу від картинок медіареальності, концентруючись на фактах, логіці, цифрах. Також треба враховувати, що під час взаємодії людини з мережевими структурами відбувається деієрархізація та втрата впорядкованості, чітких підстав для самоідентифікації внаслідок відкритості, мінливості й децентралізованості самих мереж.

Пріоритетним під час побудови когнітивних стратегій виступають комунікативні навички, а також навички критичного і творчого мислення. Найчастіше однією $з$ ключових когнітивних стратегій постає комунікативний досвід (найзагальніше його можна витлумачити як обмін даними чи інформацією, емоціями й цінностями за допомогою системи знаків шляхом кодування та декодування. І однією з проблем тут є виникнення розбіжностей у розумінні через багатозначність знаків і контекстуальну природу тлумачення). I тут варто зазначити, що мережева комунікація постає своєрідним розширенням звичайних комунікативних практик. У ній кардинально змінені можливості пам'яті, швидкість мисленнєвих 
операцій, перебіг часу (він, на противагу звичайному живому послідовному плину, є імпульсним) тощо. Під час комунікації в мережі смисли й когнітивні процеси загалом вплітаються в структуру мережевої логіки. Вони стають нелінійними, полісемантичними, синергічними, тотальними (людина почувається завжди на зв'язку). Ще однією особливістю такої комунікації є те, що розуміння повідомлень певною мірою задається наперед. Якщо в живій комунікації від людини вимагається активність, творчість для сприйняття і творення сенсів, розуміння контекстів, то інформація в медіа та мережі так потужно захоплює всі ресурси уваги, що на аналітику та активізацію творчих здібностей не залишається часу. «Кінцевою метою дій і інтервенцій у будь-якому з просторів (фізичному, інформаційному, віртуальному) є вплив на когнітивний простір, який покликаний модифікувати рішення об'єкта впливу. Ця когнітивна трансформація може бути разовою й несистемною, а може поміняти всю модель світу як окремої, так і масової свідомості... Когнітивні трансформації можуть йти як із боку практичного опису дійсності (наприклад, новини можуть акцентувати на одному наборі подій і засуджувати інший), так і з боку теорії (наприклад, пострадянська економіка, політологія та інші науки стали будуватися на інших підставах). Нова практична (буденна) модель світу, яка входить не тільки 3 новинами, але і з новою літературою і мистецтвом, починає відповідати своїй теоретичної моделі» [5, с. 81].

В інформаційному суспільстві перестають бути визначальними загальні поняття, на основі яких індивід себе ідентифікував би. Свідомість і пізнавальна діяльність, згідно з ідеєю А. Тофлера [6], перетворюються 3 універсальної на кліпову. Це означає, що відбувається відхід від загальнозначимих, усталених і повторюваних когнітивних схем мисленнєвого процесу до короткочасних і нестійких, які подаються інформаційними фрагментами у вигляді уривків новин, теорій, реклами та ін. I все це часто не має концептуальної підстави, $€$ швидкоплинним. Виникають проблеми на зразок того, як у такому плюральному середовищі 3 тотальною фрагментованістю зберегти стійку ідентичність або ж на підставі яких критеріїв ідентифікувати добро і зло, технології, які утверджують життя і є конструктивними для людини та соціуму від тих, які ведуть до руйнації і деградації? Новий код структури реальності подається через призму інформаційних фільтрів, які змінюють усі антропоструктури. Найважливішими цінностями постають інформація і знання. Однією 3 ключових імплікацій інформаційних ресурсів $€$ їхня всеохопність, а людські можливості сприйняття та обробки інформації обмежені. Саме це співвідношення між інформаційними ресурсами та когнітивними здібностями і визначає динаміку соціальних взаємодій, структуру життєвого світу людини загалом. Також можна стверджувати, що практики репрезентування реальності в медіа та мережі прямо корелюються 3 фундаментальними онто-антропологічними проблемами людини, якот самоідентифікація, вибір рольових моделей поведінки, стилю думок, діяльності та іншого.

Отже, когнітивні стратегії можна визначити як відносно стійкі форми оцінки та репрезентації дійсності на основі суб'єкт-об'єктної взаємодії зі світом. У зв'язку з трансформацією сучасної культури та перебудовою знаково-символічної системи в нових видах інформаційної комунікації ці стратегії також модифікуються. Когнітивні стратегії залежать від рівня самосвідомості людини, від характеру іï інформаційних взаємодій, ціннісної ієрархії, установок та іншого. У сучасному світі такі стратегії втрачають свою стабільність. Загалом, можна говорити про такі стратегії, як: суб'єктивний вибір інформації, що найбільше узгоджується 3 очікуваннями та перевагами індивіда, виходячи з його світоглядних установок i пріоритетів; пасивне сприйняття найдоступнішої інформації (тобто такої, що багаторазово повторюється, легко засвоюється й не потребує особливих зусиль для сприйняття (тут найперше можна говорити про продукти маскульту)), разом 3 якою в мережі швидко поширюються фейки, постправда, домисли, квазінаукові дані та інше; самостійний критичний пошук достовірної інформації (наприклад, через співставлення та критичний аналіз різних джерел). Можемо виокремити такі чинники, які впливають на когнітивні стратегії: емоційність, багатократна повторюваність, агресивність, відвертання уваги. Сучасні медіатехнології не тільки збільшують когнітивні можливості індивіда, але й трансформують його світобачення в бік утвердження нестабільності, розмитості ідентичності, ціннісного ацентризму. Тому однією з когнітивних адаптивних стратегій у такій ситуації бачиться формування динамічної стійкості та рівноваги завдяки балансу стійких та динамічних елементів, розвиток критичного аналітичного мислення.

\section{Jimepamypa}

1. Ван Дейк Т.А. Язык. Познание. Коммуникация : Благовещенск : БГК им. И.А. Бодуэна де Куртене, 2000. 308 c.

2. Луман Н. Реальность массмедиа. Москва : Праксис, 2005. 256 с.

3. Ожеван M.A. Homo ex Machina. Філософські, культурологічні та політичні передумови формування конвергентного суспільства : монографія. Київ : НІСД, 2017. 272 c.

4. Петрушенко В.Л. Тлумачний словник основних філософських термінів. Львів : Видавництво Національного університету «Львівська політехніка», 2009. 264 c. 
5. Почепцов Г. (Дез)информация : монография. Київ : ПАЛИВОДА А. В., 2019. 248 с.

6. Тоффлер 0. Раса, власть и культура. Новая технократическал волна на Западе: монография. Москва, Прогресс, 1986. С. 276-288.

7. Флюссер В.О проецировании. ХОРА: журнал совреленной зарубежной философии и философской колпаративистики. 2009. № 3/4 (9/10). С. 65-76.

8. Dole J., Nokes J., Drits D. Cognitive Strategy Instruction : Researchgate.net : вебсайт. URL: https:// www.researchgate.net/publication / 268425680 Cognitive_Strategy_Instruction_Cognitive_Strategy_ Instruction (дата звернення: 15.12.2020).

9. Floridi L. The philosophy of information. Oxford : Oxford university press, 2013. $403 \mathrm{p}$.

10. Floridi L. The Informational Nature of Personal Identity. Minds Machines. 2011. № 21 (4). P. 549-566.

11.Kahneman, D. Thinking, Fast and Slow. New York : Farrar, Strauss, Giroux, 2011. 512 p.

12. When Tech Knows You Better Than You Know Yourself : Wired : вебсайт. URL: https://www.wired. com/story/artificial-intelligence-yuval-noah-hararitristan-harris/ (дата звернення: 17.12.2020).

\section{Анотація}

Онищук О. В. Динаміка трансформації когнітивних стратегій в умовах інформаційного плюралізму. Стаття.

У статті аналізується зміст понять «когнітивна стратегія» та «когнітивна схема» в ракурсі проблем, які виникають через активний вплив інтернет-мережі на медіареальності на когнітивні структури людини та модифікації картини реальності. Показано, що когнітивні стратегії і схеми в інформаційному просторі сучасності зазнають потужного впливу мережі та медіа, під впливом останніх змінюються комунікативні, аксіологічні, соціальні та екзистенційні виміри людини. Наголошується, що когнітивні зміни відбуваються шляхом створення нових ментальних структур або трансформації вже наявних, а практики репрезентування реальності в медіа та мережі прямо корелюються 3 фундаментальними онто-антропологічними проблемами людини, як-от самоідентифікація, вибір рольових моделей поведінки, стилю думок, діяльності та ін. Розглянуто особливості взаємодії людини з медіареальністю та інтернет-мережею і те, як останні впливають на когнітивні здібності людини. Наголошено, що когнітивні стратегії залежать від рівня самосвідомості людини, від характеру їі інформаційних взаємодій, ціннісної ієрархії, установок. Обгрунтовано, що дуже часто такі впливи несуть у собі маніпулятивні інтенції, які стимулюють споживацтво, некритичність, безвідповідальність та ін. Встановлено, що однією 3 ключових імплікацій інформаційних ресурсів є їхня всеохопність, а людські можливості сприйняття та обробки інформації обмежені. Саме це співвідношення між інформаційними ресурсами та когнітивними здібностями і визначає динаміку соціальних взаємодій, структуру життєвого світу людини загалом. Тому перспективною бачиться стратегія формування динамічної стійкості та рівноваги завдяки балансу стійких і динамічних елементів, а також розвиток критичного аналітичного мислення в поєднанні із застосуванням оптимальних комунікативних стратегій.

Ключові слова: когнітивна стратегія, медіареальність, комунікація, інтернет-мережа.

\section{Summary}

Onyshchuk O. V. Dynamics of transformation of cognitive strategies in the information pluralism. - Article.

The article analyzes the meaning of the concept of "cognitive strategy" and "cognitive scheme" in the perspective of problems that arise due to the active influence of the Internet on media reality on human cognitive structures and modifications of reality. Cognitive strategies and schemes in the information space of today are strongly influenced by the network and media, under the influence of the latter change the communicative, axiological, social and existential dimensions of man is shown. The author emphasizes that cognitive changes occur through the creation of new mental structures or the transformation of existing ones, and the practices of representing reality in the media and network are directly correlated with fundamental onto-anthropological human problems, such as self-identification, choice of role models, style of thought, activity, etc. The peculiarities of human interaction with media reality and the Internet and how the latter affect a person's cognitive abilities are considered. It is emphasized that cognitive strategies depend on the level of human self-awareness, on the nature of its information interactions, value hierarchy, attitudes. It is substantiated that very often such influences carry manipulative intentions that stimulate consumption, uncriticalness, irresponsibility, etc. It has been established that one of the key implications of information resources is their comprehensiveness, and human capabilities of information perception and processing are limited. This relationship between information resources and cognitive abilities and determines the dynamics of social interactions, the structure of the human life in general. Therefore, the strategy of forming dynamic stability and balance due to the balance of stable and dynamic elements, as well as the development of critical analytical thinking is considered promising.

Key words: cognitive strategy, media reality, communication, Internet network. 